\title{
Between the EU and Russia: Geopolitical Games in Belarus
}

\author{
BY
}

\section{DAVID MARPLES*}

The three-way relationship between Belarus, Russia, and the European Union has often been discussed, particularly concerning what seems to be a tug-of-war for the allegiance of Belarus between two power bases: the one a traditional ally and regional power; the other an important economic partner with political ambitions.

But it has less often been portrayed for its prevailing characteristic: a convenient instrument deployed by the Lukašenka regime in Belarus to keep itself afloat. Official Belarus has achieved this feat in a number of ways that will be explored in this paper.

Although relations with the EU deteriorated after the brutal crackdown on demonstrators after the December 2010 presidential elections in Belarus, relations with Russia, which had been frigid between 2008 and 2010, improved by the end of the latter year, and Belarus began to play a more active role in the CSTO and to enjoy favoured status with reduced prices for imported oil and gas.

On the other hand, by 2012, Belarus had become more reticent about sales of valuable companies to Russia, according to official pronouncements. Many Belarusians feared the consequences of Russia's raising energy prices or reducing Belarusian imports and thus by early 2013, it was hardly surprising to see the president once again reaching out to Brussels with an olive branch (Korovenkova 2013).

This paper attempts to answer the question whether the current Belarusian regime can continue to manipulate its relations between the two centres and survive growing external and internal pressures from the EU and Russia, and the economic difficulties that surfaced in 2009 and still pose problems.

It addresses as a secondary issue what it perceives as the key question of EU

\footnotetext{
* David Marples, PhD is a Distinguished University Professor in the Department of History and Classics, University of Alberta, Canada. He is also President of the North American Association for Belarusian Studies.
} 
policies toward Minsk and whether they are expedient, justifiable, and have potential for success. In order to answer this question, I have deemed it necessary to look into the background of the EU-Belarus relationship over the past six years at the elite level in detail in order to ascertain the reasons for the current impasse. I have devoted less space to the history of the links with Russia, which requires a lengthier treatment.

I note, however, how Belarus agreed eventually to membership in a variety of Russian-led or dominated formations that hitherto had amounted to very little. These include the CIS, the Russia-Belarus Union, the Collective Security Treaty Organisation, and finally the Customs Union with Russia and Kazakhstan. Belarus' participation in these earlier bodies had been half-hearted, partly because the terms of membership were never satisfactorily elaborated or else Minsk considered that Moscow's role was too large.

The most critical aspect for Minsk is the economic one, that is the extent to which Belarus is dependent on Russia and the impact of this reliance on the political partnership. The chief focus of the paper is the two years following the December 2010 presidential elections, but to introduce this period, we will look at the background in 2006-10 in some detail, a period that followed the enlargement of the EU to include Belarus' neighbours Latvia, Lithuania, and Poland, in 2004.

\section{Relations with the EU, 2006-2010}

There have been a number of efforts by scholars to analyse the topic of EU policy toward Belarus. Some have been quite critical of the responses from Brussels to events within the eastern country and have argued that EU policy lacks consistency or that its treatment of Belarus - especially the imposition of sanctions - is predicated on moral behaviour rather than the needs of a pragmatic approach of engagement.

For example, writing in 2009, Giselle Bosse argues that 'the EU's approach towards Belarus is clearly torn between idealist values of democracy promotion and (largely rhetorical) support of bottom-up civil society on the one hand, and the realist objective to support 'state-stability' through strategic institution-building assistance on the other hand' (Bosse 2009, 224). Another analyst reached a more critical conclusion:

rather than 'access', and be modestly disregardful of the cultural and geopolitical diversity of its neighbourhood, and the boundaries of others (Korosteleva 2009, 243).

Others similarly have criticised the usage and expansion of sanctions against 
Belarus as a means of punishment for its failure to release political prisoners, arguing either that EU policy is inconsistent, particularly with regard to the EaP member states because it has singled out Belarus for punishment, or else that sanctions are ineffective and have the undesired result of ensuring that the country moves inexorably into the economic and political-security orbit of Russia (Melyantsou and Pikulik 2012, Ioffe 2012). In short, it is claimed that sanctions are self-defeating, whereas engagement would be a more productive course of action, though it would mean ignoring the harsher aspects of the Minsk regime. Is this a logical approach?

In a working paper, Balazs Jarabik and Alastair Rabagliati comment that the EU presence in Belarus is too low keyed. They cite, for example, the fact that only eleven European embassies were operating in Minsk and no Commission Delegation, the latter having been delayed for lack of financing because the country is not considered a priority. They write also of a 'lack of visibility' of the EU in Belarus and the fact that it does not have the tools to engage with the local population. They regard the latter as the second vital policy, the first being that 'dialogue' should be conditional on democratic improvements.

And while aid from the European Commission has provided annually 10 million Euros to the country, it has been mostly through the TACIS program for specific projects such as humanitarian aid for problems resulting from the 1986 nuclear accident at Chernobyl, nuclear safety, and regional activities, rather than democracy promotion, education, and assistance to nongovernment NGOs. Among their recommendations are the enhancement of the EU profile, the promotion of energy efficiency, assisting better contacts with neighbours and revisiting the issue of the price of Schengen visas for Belarusian residents, and the creation of a European Foundation for Democracy.

They would also like to see better means of supporting political parties in ways that can circumvent the limitations of EU Financial Regulation (Jarabik and Rabagliati 2007, 1-2, 14-15). This paper has become a little dated with time, but its general criticisms remain pertinent. On the other hand, the profile of the EU five years later seems considerably higher, not least as a result of the pro-European policies advocated by several opposition candidates in the 2010 presidential elections.

Independent Belarus' initial relationship with the EU had been undermined by the Lukašenka regime's constitutional amendments and referenda conducted in 1995 and 1996, by which the authority of the parliament and Constitutional Court were severely reduced and the country adopted a system of authoritarian presidency. 
These moves came after an early period of some promise for a more democratic path following Belarus' transition to an independent state in the summer of 1991, and the emergence of Stanislaŭ Šuškevič as a nonpartisan leader of the Parliament. In 1989 the European Community had signed a Trade and Cooperation Agreement with the USSR, which was followed by a Partnership and Cooperation Agreement (PCA) with Belarus (1995), as well as an Interim Trade Agreement to stay in place until all members ratified the PCA. The measures taken by the Lukašenka presidency interrupted that process, and in 1997 relations were frozen, and the PCA ratification suspended. Subsequently there were no high-level contacts with the Belarusian government (Bosse 2009, 219-20).

In 1999-2000 there was a series of kidnapping and disappearances of leading public figures that no longer wished to work with Lukašenka, including the deputy chairman of the former Supreme Soviet, Viktar Hančar (the president's campaign manager in the 1994 presidential elections), businessman Anatol Krasoŭski, Lukašenka's former personal cameraman, Dzmitry Zavadski, and the former Minister of Internal Affairs, General Jury Zacharenka (Civil Initiative 'We Remember' 2011).

These events have never been explained or resolved despite constant requests both from the opposition and from the Europeans. Subsequently the main contacts between the EU and Belarus were through embassies, the TACIS office in Minsk, and indirectly through the OSCE office, headed by Hans-Georg Wieck, the former West German ambassador to the USSR. Relations with Wieck became fractious following his role in both an attempted dialogue between the authorities and the opposition, and his part in prompting opposition parties to choose a common candidate (trade union leader Uladzimir Hančaryk) in the 2001 presidential elections.

As a result Wieck's visa was not renewed and after his departure the office was briefly unoccupied and afterward played a less intrusive role in Belarusian political life after a Memorandum of Understanding was signed between the OSCE and the Government of Belarus on 1 January 2003. Subsequently the office remained in place until Belarus abruptly ended the OSCE mission after the 2010 elections (Organisation for Security and Co-operation in Europe, Office in Minsk). Following EU enlargement in 2004, the TACIS (Technical Assistance to CIS countries) Office was later expanded into an EU Delegation.

In both 2006 and 2010, presidential elections ended with mass arrests and imprisonment of alternative candidates, as well as dozens of others. Yet it was precisely elections that determined the future course of the relationship between Belarus and the EU. They have constituted a period when the authoritarian regime, in place since the summer of 1994 , has to open up, at least partially. 
In November 2006, in response to the arrests of political prisoners that followed the elections, the EU had put forward twelve conditions for engagement with Belarus based on a 'non-paper' entitled 'What the European Union could bring to Belarus', which argued that it would be possible for the country to receive similar benefits to its neighbours, Latvia, Lithuania, and Poland, who had joined the Union two years earlier. The Belarusian people had an opportunity in this way to improve their quality of life, as well as facilitated travel to the EU. There were also proposals for better cross-border cooperation, EU support for the development of small and medium factories, and the enhancement of health care and education. Other areas for common work included the environment, food safety standards, working conditions, and modernization of transport and energy networks. Belarusian students would have more opportunities to study in universities in EU countries and the Belarusian market could benefit from closer access to some 480 million consumers in Europe. Lastly, but of prime importance, the EU would offer increased financial help to its partner (European Union External Action 2006).

The non-paper noted, however, that Lukašenka's policies did not permit such an engagement because it was denying its citizens their basic democratic rights. It stipulated the fulfilment of twelve conditions first (European Union External Action 2006):

- Democratic elections, including the right of opposition candidates to campaign freely

- Free expression and the right of journalists to conduct their activities without harassment

- Full rights for NGOs

- The release of all political prisoners, which included those in opposition parties, NGOs, and others arrested at public demonstrations

- A review of cases of those who 'disappeared' in 1999-2000 (Zacharenka, Hančar, Krasoŭski, and Zavadski)

- An impartial and independent legal system

- The ending of arbitrary arrests and incarcerations

- Full rights for national minorities

- Workers' rights, including the right to join (an independent) trade union

- Full rights for entrepreneurs (small businessmen) to operate without hindrance

- The abolition of the death penalty in concert with the other countries of Europe

- To accept support from the OSCE, EU, and other agencies were willing to assist Belarus and support popular rights.

Concerning the aspirations of the EU, the situation vis-à-vis Belarus appeared to improve by 2008 with the release of most political prisoners prior to the parliamentary elections - most notably former presidential candidate and former 
Rector of Belarusian State University, Aliaksandr Kazulin. Therefore on 13 October 2008, the foreign ministers of the 27-member countries of the EU met in Luxemburg and agreed to lift the travel bans on all but five members of the Lukašenka administration for a 6-month trial period (Cassatas 2008). ${ }^{1}$

Though not specifically stated in official bulletins, the Russian war with Georgia was one of the likely catalysts for the move to end the ostracising of Belarus though such measures were a natural progression of earlier plans. The EU also reconsidered its original 12 points, which were unacceptable to the Minsk authorities and not widely circulated among the Belarusian public, to focus on three essential ones: democratic elections, a free media, and free assembly and political associations.

Such a 'concession' indicated to at least one observer a certain inconsistency in the EU's position (Lisichonak 2012). To the Lukašenka regime it indicated that there was room for manoeuvre concerning EU demands, and they could be based on bargaining between the two sides. Subsequently this conception of 'negotiating' over various points was evident in the position of official Belarus. From the viewpoint of the EU, the possible link to the war in Georgia implied that there were geostrategic and economic reasons driving the apparent rapprochement with the Lukašenka regime. Thus, as with Ukraine and Georgia, it might be possible to attract the Belarusians to the European fold. In the background in this period was invariably the issue of Belarus' role as a conduit for Russian gas and oil to EU consumers through the Druzhba pipeline, which accounted for about $25 \%$ of supplies (most of the supplies came through Ukraine).

Subsequently, Belarus was invited to become a member with a regional initiative of the European Neighbourhood Policy under the mantle of the European Commission, called the Eastern Partnership, which held its founding meeting in Prague in May 2009. The criteria for what is described as a 'privileged' relationship with the EU were the same as those for the ENP, i.e. that the partner state conducts good government in the pursuit of democracy, human rights, and the rule of law, and introduces market principles in its economy.

Countries deemed to be performing well in those areas were invited to agree on a bilateral Action Plan with a program of economic and political reforms over a period of 3-5 years. Belarus did not reach that stage in 2009 and at the time of writing remained the only European country in the ENP not to have agreed on a common plan (despite discussions of a joint interim action plan) (European Commission 2011). The other partners of the Eastern Partnership are Armenia,

\footnotetext{
1 The exceptions were Lidzija Jarmošyna, chairperson of the Central Election Commission; Minister of Internal Affairs Uladzimir Navumaŭ; Dzmitry Paŭličenka, former commander of that ministry's special response forces; Viktar Šejman, former Secretary of the Security Council; and Minister of Sports and Tourism Jury Sivakaŭ.
} 
Azerbaijan, Georgia, Moldova, and Ukraine, and the EU has agreed to support the EaP with funding of $\$ 2.6$ billion in bilateral and regional programming. In January 2010, the EU declared its intention to replace the original Partnership and Cooperation Agreements (PCAs) with new Association Agreements (AAs) (EU Council Secretariat 2011, 1-2).

\section{The Belarusian Presidential Elections of 2010}

The presidential election campaign and its aftermath Belarus on 19 December 2010 , proved to be a critical turning point for the country's relationship with the EU. They took place amid the fractious dispute with Russia (it ended on 9 December after a meeting between the respective presidents in Moscow) and encouragement from the Europeans to Lukašenka to conduct a more democratic campaign than in the past.

In November, two EU foreign ministers visited Minsk - Guido Westerwelle of Germany and Radoslaw Sikorski of Poland - and held a meeting with the Belarusian leader during which he was informed that if the election were carried out fairly, they would seek to facilitate a loan of $\$ 4.3$ billion from the EU, with the assistance of the International Monetary Fund (IMF) (Center for European Policy Analysis and Freedom House 2011, 10).

In the immediate neighbourhood of the EU, Lukašenka also received encouragement from Lithuanian president Dalia Grybauskaite, who expressed her personal view that a return of Lukašenka to office would be the most favoured result as the best guarantee of stability (Charter'97 2010). There was no shortage of candidates: initially the Central Election Commission registered nineteen candidates. However, only eleven gathered the requisite minimum 100,000 signatures, and one of those - Siarhiej Hajdukievič, leader of the Liberal Democratic Party - decided to drop out, claiming that 'the election in Belarus is a show, and its results have been known long enough' (Pulsha 2010).

European hopes that the election would be conducted more fairly were to some extent met in that it was possible for opposition candidates to campaign more freely than in the past. Several issues divided the candidates. First, there was the question of the attitude toward Russia and whether to try to exploit the apparent rift between Lukašenka and his counterpart Medvedev and Russian Prime Minister Vladimir Putin. Whereas some candidates tried openly to cultivate a following in Russia - none was successful - others regarded such moves as unpatriotic and counter-productive.

Second, whereas several opposition candidates were oriented primarily toward the EU - Andrej Sannikaŭ, Aleś Michalievič, and Ryhar Kastusioŭ being the most 
obvious - they were clearly frustrated by the ostensible 'deal' made between EU leaders and Lukašenka. For many of them the very existence of the Eastern Partnership was a sign that they had been bypassed and the Europeans found it more expedient to deal directly with the government.

The Belarusian leader also fostered this impression by making contemptuous remarks about opposition leaders and refusing to debate with them on television. Third, there were simply too many candidates for the electorate to swallow. It became a difficult task even when platforms were published in the media to discern one from another and all too easy for Lukašenka to treat them collectively. In fact he dismissed them all as fighting among themselves for foreign grants meaning that they were unable to consolidate around two-three candidates (Volyanyuk 2010b).

The Belarusian electorate recalled the elections of 2006 and the selection of a 'unified' candidate Aliaksandr Milinkievič as the representative of the United Democratic Forces. But on 17 September 2010, Milinkievič, the best-known opposition leader and the leader of the Movement for Freedom decided not to run in the December elections (European People's Party Group in the European Parliament website 2010). ${ }^{2}$ He maintained that the government had declined to amend the election regulations to enable a free and fair contest, but he may also have dropped out because of lack of donor support (Aliaksandr Milinkievič web site). His departure only made the picture more complicated, particularly in terms of public focus.

A bewildering array of alternatives emerged, from former deputy foreign minister Sannikaŭ, former leader of the Writers' Union of Belarus ['Tell the Truth' leader] Uladzimir Niaklajeǔ, Green Party leader Jury Hlušakoŭ, seasoned veteran Nikolaj Statkievič of the Social Democratic Party, Kastiusoŭ of the Belarusian Popular Front, economist Jaraslaǔ Ramančuk, and youthful figures like Michalievič and Vitál Rymašeǔski, co-leader of the unregistered Belarusian Christian Democratic Party (Marples and Padhol 2010).

Lukašenka did not take an active part in the campaign, but was featured on television at official meetings or with foreign dignitaries; in short he fostered the impression that he was busy attending to the business of the country. During the runup to the election, one observer summarised the situation perceptively as follows: everyone would like change, but no one believes that he/she personally is able to impart much influence or that the elections will bring it about' (Shumchenko 2010).

2 Milinkievič also has a very good reputation in the EU. In October 2006, he was awarded the Sakharov Prize for Freedom and Thought by the Conference of Presidents of the European Parliament, whose previous winners had included Kofi Annan and Nelson Mandela. 
Why Lukašenka's well-prepared campaign was followed by the post-election crackdown remains a matter of conjecture and debate - as do also the reasons for his earlier policy of more cooperation, other than that it coincided with a time of difficult relations with Moscow. The violent response of the riot police to a demonstration in Independence Square occurred after they reacted to an apparent attempt to break into the parliament building (Vashkevich 2010). By the end of the night, over 700 people had been arrested, many after being attacked with truncheons.

Niaklajeŭ was detained and beaten before he even got to the original meeting site at October Square. Later he was removed from his hospital bed by several men and taken to a KGB isolation cell. Sannikaŭ was also beaten and arrested. The events indicated not only the fear of the regime of being replaced but also careful preplanning. Some known activists were arrested the day before the elections, including Youth Front leaders Dzmitry Daškievič and Eduard Lobaŭ. Several of those detained were subsequently subjected to torture (Charles 2011). ${ }^{3}$

In many cases the KGB tried to solicit confessions and would offer freedom in return for cooperation against alleged state enemies. Ramančuk appeared on television and denounced those who had entered Independence Square for threatening the lives of innocent civilians. Both Kastiusoŭ and businessman Viktar Ciareščanka endorsed his position, though his own party, the United Civic Party, denounced his statement on its website (United Civil Party 2010).

Still the reasons for the overreaction by the authorities remain unclear, particularly when the victory of Lukašenka, in the fairest election since 1994, was clearly assured. One suggestion has been advanced by formerly detained political prisoner Dzmitry Bandarenka, namely that KGB officers were taken aback by the size of the rally and the intention of the opposition to negotiate with then Prime Minister Siarhiej Sidorski (Charter‘97 2012b).

Enough voting stations had counted votes accurately to indicate that the president had failed to win an outright majority - no more than $40 \%$ - and that Sannikaŭ's support was $25-30 \%$. Thus there would have to be a second round (Charter'97 2012). The unprecedented situation would have been an embarrassment to Lukašenka and presented him with a serious rival. Bandarenka was the head of the Sannikaŭ's election campaign and thus his analysis may err on the side of optimism regarding the support for his candidate.

3 At a press conference by Aleś Michalievič on 28 February, he provided a detailed account of the various forms of torture deployed. He had been released on condition that he turn KGB informant. Instead he gave a graphic account of the conditions in his cell and tortures applied. Two days later, he managed to escape Belarus and fled to the Czech Republic where he was granted political asylum. 
On the other hand there was no indication from independent pollsters that Lukašenka would receive almost $80 \%$ of the votes, his officially reported total. Similarly the return cited for Sannikaŭ - just over $2 \%$ - seems considerably understated. Yet misreporting of election results has been the common practice of the Belarusian Central Election Commission since 2001. Possibly the authorities feared some sort of attempt by the opposition to seize power, though there is little evidence that any of its leaders nurtured such a conception.

\section{European Response to the Belarus Elections}

The response of Europe to the violence and arrests in central Minsk took time to develop but the response from the two ministers who had encouraged the Belarusians to provide a free and fair election was immediate. Together with the Foreign Ministers of Sweden and the Czech Republic, Carl Bildt and Karen Schwarzenberg, Westerwelle and Sikorski published an editorial in The International Herald Tribune entitled 'Lukashenko the Loser', stating that it was impossible to do business with such a leader. They declared that the announced election result 'has no democratic legitimacy whatsoever' and that 'Europe has not seen anything like this in years'. The vote rigging and assault by the police, they added, 'makes what Miloševič tried to do in Serbia in 2000 pale in comparison'.

For the writers, it would be frittering money to expend it on further engagement with the Belarusian president. The European Union stood for the rule of law, human rights, and democracy and could not stand aside when these values were being flouted 'in its own part of the world'. Instead of dealing with the leader of Belarus, the EU should 'deepen [engagement] with the democrats of Belarus' as well as with government figures that disagreed with the harsh policies carried out by Lukašenka (Bildt, Schwarzenberg and Sikorski 2010). It was the strongest attack on the president to date from well-known figures in the EU and indicated their disillusionment.

The response elsewhere in Europe was slower, but equally forthright. The Foreign Minister of Lithuania, Audronius Azubalis, demanded that all political prisoners be released immediately and provided with medical attention. He also criticised as 'unconvincing' the statement from Minsk that the OSCE had fulfilled its mandate and thus the mission had been discontinued (Azubalis himself would have been the incoming chair). On 12 January Catherine Ashton, the EU High Representative for Foreign Affairs and Security Policy, met with the then Belarusian Foreign Minister Siarhiej Martynaŭ in Brussels and threatened him with 'appropriate measures' if there were any delays with the release of members of the opposition, journalists and others (Rettman 2011a). 
President of the European Parliament Jerzy Buzek met on this same day with several leaders of the opposition and informed them of a prospective change of policy and the Europeans' firm solidarity with the Belarusian people. He compared the situation in Belarus with that of the Solidarity Union in Poland in the early 1980s, and expressed his confidence that in the long term those who opposed Lukašenka would win. He declared that the regime in Minsk had no legitimacy and that Poland had already responded by doubling its assistance to Belarusian civil society and NGOs from $\$ 6.5$ to $\$ 13$ million. He commented also that Poland would not allow those responsible for the crackdown to travel from Belarus (RIA Novosti 2011).

On 7 January 2011, three weeks after the Belarusian elections, EU ambassadors met in Brussels and decided to lift the suspension on the visa ban imposed originally after the 2006 presidential elections. At that time the ban pertained to some 40 officials, headed by Lukašenka. Its suspension had been renewed in October 2010, although other sanctions were left in place, mainly concerning financial assets of these same figures in EU countries.

There was unanimity that a strong message was needed in light of the repressive actions of the Belarusian authorities. The list of banned officials was published in a Belarusian opposition newspaper in early February and included the names of 158 officials (Rettman 2011b). Subsequently it was expanded to 192, with the inclusion of some of the judges and prosecutors handing down sentences to those arrested in the aftermath of the elections. The brief interlude of dialogue and engagement appeared to be over.

In turn, Lukašenka declared that Poland and Germany had conducted spying missions in Belarus and that there was a foreign plot to overthrow his regime with the aid of a fifth column from the Belarusian opposition (Schwirtz 2011). The Belarusian authorities also embarked on a thorough crackdown on opposition and human rights organisations and NGOs, which in its ruthlessness was as severe as anything seen previously in the 17 years in which Lukašenka had been in power. Thus relations between the EU and Belarus appeared to have reached a new impasse.

\section{Relations with Russia}

The EU policy of isolating Belarus always ran the risk of pushing the Belarusians into the arms of Russia, with which Belarus has maintained a formal Union Treaty since 1997. However, the bilateral relationship between the two states, as with the respective presidents experienced a series of fluctuations from the early 21st century, despite the signing of a formal 'Union' in April 1997 and the formal 
existence of a Union state thereafter. Russia was also working through other integrative organisations into which it wished to co-opt Belarus, including the Eurasian Economic Community, and the desire to form a Common Economic Space and common currency.

The initial confrontation between Vladimir Putin and Aliaksandr Lukašenka in 2002 was over the terms of the Union, but relations worsened once Russia decided to stop subsidising supplies of gas to its neighbour and insisted - through the company Gazprom - that Belarus must pay market prices. Belarus objected additionally to Russia imposing customs fees for its oil exports across the border (RIA Novosti 2010). Matters were made more complicated by the world recession that started in 2008, which together with the end of Russian subsidies created a foreign currency crisis in Belarus that had yet to be resolved by early 2013, and which resulted in spiralling inflation and devaluations of the state currency.

Further, Belarus became dependent on foreign loans to keep its economy afloat, which has weakened its position vis-à-vis Moscow. The two sides also embarked on a so-called 'milk war' in June 2009 when Russia imposed a ban on imports of Belarusian dairy products, leading to the refusal of Lukašenka to attend an important summit of the Collective Security Treaty Organisation (CSTO) in Moscow. The imposition followed Belarus' refusal in May to accept a $\$ 500$ million stabilization loan in Russian roubles. Instead it accepted a further 1 billion Euros on top of an already agreed loan from the IMF (Silitski 2009). Clearly, Belarusian policy was driven by two factors: its economic problems and the dual vector foreign policy between the West (this time represented by the IMF) and Russia.

On 5 July 2010 at the Interstate Council of the Eurasian Community in Astana, Kazakhstan, Russia, and Belarus agreed to establish a Customs Union, with a free trade zone established within a year, and the Common Economic Space to be in place by 1 January 2012 (Volyanyuk 2010a). Almost simultaneously, in what was unlikely to have been an independent decision, the NTV network broadcast the first of four instalments of a documentary on its 'Emergency Situations' segment entitled 'Krestnij Baćka' (Godfather), a highly critical account of Lukašenka's regime that discussed the kidnappings of leading statespersons in 1999-2000 and provided a scathing portrait of Lukašenka's private life - he lives separately from his wife and has an illegitimate son who accompanies him regularly - as well as commenting adversely about his lack of cooperation within the Russia-Belarus Union.

What seemed to have particularly angered the Russians was Lukašenka's failure to recognise the independence of the two breakaway republics that emerged after the war with Georgia, Abkhazia and South Ossetia. On 3 July, Russian president Dmitry Medvedev had also criticised an open letter from Lukašenka to 80 Russian businessmen, which provided the Belarusian perspective on the continuing gas 
crisis and the terms of the Customs Union (Buhaj 2010). Thus some five months before the election relations with Russia seemed to have reached a new low level. On the other hand, the harsh language seemed to be a common feature among the hierarchy of the post-Soviet republics. Relations between Russia and Belarus were tense, but not severed.

For the Belarusian leadership, in the period 2008-10 relations with Moscow were unpredictable therefore, and there was ample evidence that the Russian authorities were quite willing to allow public attacks on Lukašenka on their TV networks. Yet once again as far as the latter was concerned, his preoccupation was less with moral questions or transition to democracy or privatization than his freedom of manoeuvre. It was in short a power game in which he could only avoid defeat by his eastern neighbour by conceding to some of the requests from Brussels.

Belarus' financial predicament also rendered some of the more profitable companies vulnerable to bids from Moscow. By the end of 2011, the Russian company Gazprom gained majority ownership of the company responsible for supplying Russian gas to Europe, Beltranshaz. Russian companies had also made big gains in Belarus in areas such as oil refineries, banking and insurance, and were also negotiating for mergers or takeovers of Belaruskali (worth $\$ 30$ billion according to Lukašenka), which is coveted by Uralkali, whose largest shareholder is Suleyman Kerimov, the Daghestani billionaire (Marples 2011), the MAZ truck company, and the main cellular phone company. Russian Finance Minister Aleksei Kudrin in May 2011 stated that \$7.5-\$9 billion of Belarusian public assets should be made available for some purchases from his country, in return for a $\$ 3$ billion stabilization loan offered through the Russian-led Eurasian Economic Community (Ministry of Finance of the Russian Federation 2011). The implication, according to one analysis was that Russian intended to control 'the Commanding Heights of the Belarusian Economy', after which it would not be possible for a leader of Belarus to work against the economic interests of Moscow (Coyle 2011). Once again, the pragmatic president looked for an opportunity to turn westward provided that some incentives were on the table. But after December 2010 that option had was no longer viable.

\section{Impact of the Financial Crisis}

Subsequent events in Belarus were overshadowed by a financial crisis that has proved to be the biggest dilemma of the Lukašenka regime to date. The situation was made worse by wage rises of up to $50 \%$ prior to the 2010 elections, which reduced foreign currency reserves to very low levels, and which, according to an IMF report, the government could not afford (International Monetary Fund 2011a). 
The government responded by printing money, thereby causing hyperinflation. There were also two currency devaluations during 2011, reducing the rouble from BYR 2,200 to the dollar to BYR 8,650 (by January 2013 the rate was BYR 8,685). The government also sought foreign loans of up to $\$ 8$ billion from the IMF - the request was still under debate a year later, pending an IMF visit to Minsk in October 2012 - and $\$ 3$ billion from the Eurasian Economic Community's Emergency Fund (as noted above). Lukašenka blamed the West for the devaluation, stating: 'What democracy can we be talking about when they use the very moment we develop problems on our currency market to try to strangle us' (Agence France Presse 2011). The inference was that problems obtaining an IMF loan were linked to the continued retention of political prisoners in Belarus. However, the IMF's recalcitrance appears to have been based more on Belarus' defective macro-economic policies and lack of economic reforms (International Monetary Fund 2011b).

In October 2011, an IMF mission arrived in Belarus led by Chris Jarvis, and recommended that the National Bank should increase its interest rates to lower the rate of inflation. It also suggested that the state should halt any further wage increases and restrain spending. The IMF did, however, approve the National Bank's unification of the currency at the market rate level and the floating of the ruble (IMF 2011b). In this same period, there was held what was described as the first EUBelarus technical dialogue on economic and financial issues in Minsk, which dealt with macro-economic and structural reform efforts in Belarus. Its recommendations did not differ substantially from those of the IMF.

Subsequently the government of Belarus under Prime Minister Michail Miasnikovič has developed a fiscally stringent program to boost exports and control spending, but first reports indicated that it had not met with the approval of the president, without which it could not come into force (European Commission 2011, Kudrytski 2011). Gradual privatization of companies has also been approved, although at a much slower pace than suggested originally by the Russians. In March 2012, the president stated that in theory, any enterprise could be sold, but there would be no 'sweeping privatization' in Belarus. On the other hand, he rejected the notion that there should be a register of selected 'strategic' companies, noting that this term had once been applied to the Beltranshaz enterprise, which was nonetheless eventually sold to Russia (Kryat 2012). Lukašenka also declared later the same month that he was willing to sell the country's most profitable company, Belaruskali (Belarus Potash), but for $\$ 30$ billion rather than the $\$ 15$ billion that had been put on the table (by the Urals Potash Company) (the official price has since risen to around $\$ 36$ billion). Belarus has a lot of profitable companies, he continued, but they would not be sold off cheaply (National Legal Portal of the Republic of Belarus 2012). The economic situation nonetheless suggests that such sales will continue and that the 
primary purchasers will be Russian companies through the medium of the Eurasian Economic Community because as former Finance Minister Kudrin requested, sales will be linked to the EuEC loan.

\section{Breaching the Wall of Isolation}

During the financial crisis of 2009-11, the Belarusian president once again began to make some overtures to the Europeans, evidently fearful of what further negotiations with Moscow might bring, particularly on the issue of prices for imported Russian gas in 2012 - an existing 5-year agreement with Russia on gas prices expired on 31 December 2011, though eventually the two sides were to reach an amicable agreement. ${ }^{4}$

In so doing he managed to breach the rather thin wall of isolation established by the Europeans quite easily, perhaps because of the EU's preoccupation with its own financial problems and the lack of unity over the correct approach to take to Belarus. Two events are particularly noteworthy in indicating that there are a number of channels of communication outside those of official diplomacy.

In late August 2011, without publicity, Nikolay Mladenov, the Foreign Minister of Bulgaria made a surprise appearance in Minsk and held a meeting with Lukašenka. Afterward Mladenov wrote a letter to Catherine Ashton, stating that the Belarusian leader intended to release four political prisoners immediately and the remainder by 1 October. It was reported also that Lukašenka wished to hold a round-table meeting with EU leaders and Russia concerning the financial crisis. By 1 September, thirteen of the twenty-eight designated political prisoners had been released, mainly comprised of younger activists (Radio Liberty 2011). ${ }^{5}$

In response to Mladenov's initiative - the move seems to have been a private initiative taken without the consent of other EU member states - the response from Brussels was cautious and perhaps summarized best by Polish Foreign Minister Sikorski, who commented that the Europeans were not about to engage in horse trading for prisoners and that the prerequisite for talks with Lukašenka was the release and pardon of all political prisoners (EU Business 2011).

In pursuing this approach, the Belarusian leader was following past practice with the release of Kazulin, the prelude to the suspension of the travel ban in 2008 and the subsequent invitation to Belarus to join the Eastern Partnership. However, if there was an agreement to release all prisoners by 1 October, it was not followed

\footnotetext{
${ }^{4}$ On 28 November, Russia provided Belarus with reduced rates for remaining gas payments for 2011 and stipulated a lower rate for 2012 .

5 Former presidential candidate Dzmitry Vus was released on 1 October 2011.
} 
by Lukašenka. Two presidential candidates, Sannikaŭ and Statkievič remained in prison, as did the Young Front's Daškievič and Lobaŭ and more than twenty others.

Also in August 2011, the Belarusian authorities made an inquiry to the Lithuanian and Polish Ministries of Justice for details of the bank account information of the Viasna-96 organisation. In the case of Lithuania, the two countries have had a law in place since 1993 for the mutual apprehension of criminals. Lithuanian's Justice Minister Remigijus Simiasus treated the inquiry as routine, regarding the request as similar to several hundred received each year. As a result of the responses of the two EU neighbours, the Belarusians arrested Viasna96's leader Aleś Bialacki on 4 August on tax evasion charges. At his trial in Minsk he received a sentence of four-and-a-half years in prison. Bialacki, who is also deputy chairman of the International Federation for Human Rights, is perhaps the best-known and most respected human rights leader in Belarus.

Evidently, Lithuania had passed on bank account information of some 400 opposition leaders as well as NGOs. In both Lithuania and Poland there were immediate internal inquiries as to how the request had succeeded. Simiasus maintained that his ministry was not aware of the names of 'famous people' in Belarus and that his ministry had not intended to bring harm to the democratic opposition. Poland started an internal review and Foreign Minister Sikorski sent an apology 'in the name of the Polish Republic' to Belarusian democrats on Twitter (Marples 2011). These incidents demonstrated that there are several avenues of communication between Belarus and its European neighbours and that EU neighbours could, unwittingly, undermine the position of NGOs. Once again, from the perspective of Minsk, such loopholes indicated weakness and a lack of consistency within the EU.

\section{The EU Partnership Summit in Warsaw}

There were further ambiguous signals from Europe at the time of the EU Partnership Summit in Warsaw on 29-30 September 2011. At a media event, Poland's Prime Minister Donald Tusk declared that Belarus might be eligible for aid of up to $\$ 9$ billion if the authorities released political prisoners and held free elections. The money would be disbursed in the form of loans from two European banks, the European Investment Bank and the European Bank for Reconstruction and Development, as well as the IMF. Lukašhenka could remain in office, assuming he was the victor in the free elections (Rettman 2011b).

The Belarusian authorities treated the offer with caution. As Lukašenka's travel ban rendered him ineligible to attend the summit meeting, the EU extended an invitation to Foreign Minister Siarhiej Martynaŭ. The Belarusian side instead 
appointed Viktar Hajsionak, Belarusian Ambassador to Poland, as head of its delegation. The Europeans were evidently irked by this decision and declined to invite the ambassador to the Summit dinner since the invitees composed heads of states and governments, after which the Belarusian Foreign Ministry stated that Belarus had decided to leave the meeting (Preiherman 2011).

In the absence of Belarus, the EP states issued a Joint Declaration about the progress of the EP, but declined to sign a Declaration on the Situation in Belarus issued by the EU leaderships. That statement ran as follows:

The Heads of State and Government and representatives of the EU and its member states express their deep concern at the deteriorating human rights, democracy and rule of law situation in Belarus, deplore the continuing deterioration of media freedom in Belarus and call for the immediate release and full rehabilitation of all political prisoners, an end to the repression of civil society and media and the start of a political dialogue with the opposition. The EU is also deeply concerned about reports that prisoners are denied access to their families and lawyers as well as to medical care while being put under psychological and physical pressure (Council of the European Union 2011).

The EaP member states clearly had various concerns. Most notably Georgian president Mikheil Saakashvili has maintained a close relationship with Lukašenka, based largely on the latter's decision not to recognise formally the republics of South Ossetia and Abkhazia. Azerbaijan, the other country most strongly opposed to signing the EU statement, is in a similar situation to Belarus concerning human rights violations and does not wish to see an EP member state admonished in this way. The other three countries were evidently more reticent, but still declined to sign.

Does this comparative leniency toward other members of the Eastern Partnership suggest ambivalence in EU policies? Had the EU overreacted to the situation in Belarus? The answer to these questions is far from simple. Belarus had not experienced a change of leadership since 1994, and appeared by comparison with some other states to be relatively stable. The Europeans, nevertheless, would have hoped by 2011 to have had some leverage over and cooperation with the government in Minsk in terms of promoting democracy. However, after the 2010 elections, and perhaps even more so in the months that followed, the Lukašenka leadership once again refrained from responding to EU demands, despite occasional encouraging rhetoric from Minsk. In short, then, the Europeans came to the conclusion that ultimately nothing was going to change in Belarus as long as Lukašenka is the president and opted for a policy of enhanced sanctions at the government level, while offering encouragement for lower-level engagement with promises of support for opposition groups. 


\section{Departure of EU Ambassadors}

Another altercation at the diplomatic level between the EU and Belarus occurred in late February 2012. Following an extension of the travel ban to 21 Belarusian officials (mainly police and judges), the Belarusian authorities requested that the Polish ambassador and EU head of delegation should return to their respective capitals for negotiations. In response, EU policy chief Catherine Ashton called a meeting of Member States Ambassadors, which opted to withdraw all EU ambassadors in Minsk 'in expression of solidarity and unity' (Korovenkova 2010).

The Belarusians responded further by limiting travel for a group of opposition leaders who had expressed support for sanctions. The expanded sanctions included further expansion of the travel ban list in the spring of 2012 to include over seventy judges from different courts of Belarus (BelTA 2012a). The number of officials on the EU travel ban list by March 2012 was around 230. The travel ban, a controversial measure both because of its limited effectiveness and the means by which it is elaborated, raises several questions about the future relationship with Belarus that have continued to engender debate.

First, the deterioration of relations at the diplomatic level may not preclude expansion of trading and lower-level connections. In 2011, for example, despite the harsh rhetoric on both sides, Belarus' exports to the EU more than doubled to $\$ 15.7$ billion, considerably improving its trade deficit. In 2010 exports to the EU had fallen by $18 \%$ (Kudrytski 2012). The EU, along with Russia, remains Belarus' main trading partner. Arguably trade with Russia is more critical because it includes the export of potash and petroleum goods, along with the imports of gas and oil, but the fact that trade with the EU has expanded despite difficult relations between Brussels and Minsk demonstrates that the relationship is not single-faceted.

When the EU chose to place a Belarusian oligarch close to the president, Jury Čyž on its blacklist, it immediately ran into problems with Slovenia, which strongly opposed the move, reportedly because Čyž's Elite Estate Company had awarded a contract to the Slovenian Riko Group to construct a hotel and other buildings in Belarus (Jozwiak and Solash 2013). Possibly the targeting of powerful oligarchs and state-run companies would bring more immediate results than travel bans on political leaders and judges, but the concern has always been that economic sanctions would harm the population of the country as much as its leadership.

Second, as the above example of Slovenia shows, the EU is not monolithic, and individual states do not necessarily concur with the official EU position of isolating the Belarusian regime. For example, Lithuanian Minister of Transport and Communications Eligijus Masiulis commented on 13 April that the EU 'should seek changes in Belarus in some other way, not by means directed against the EU 
economies', while pointing out that Belarus exports fertilisers and machinery through the port of Klaipeda, the cessation of which would mean a loss of revenue for the Lithuanian government (Belsat 2012). Conversely, there may be some divisions within the government of Belarus. Current Prime Minister Miasnikovič and his predecessor Siarhiej Sidorski both appeared to endorse programs of economic reform that went further than anything propagated by the president, although there was no indication of any alternative platforms to those of the Lukašenka.

Lastly, isolation and sanctions are not effective in bringing change to an authoritarian state, not least because of a perceived imbalance in the treatment of states in the EU neighbourhood as well as the lack of obvious alternatives to Lukašenka, who still remained the most popular politician in Belarus in the spring of 2012, albeit less so than official election results suggested.

Is the EU correct in imposing its geopolitical and moral views on a former Soviet regime if much of the population is content with its government and standard of living? Or from a different perspective, how is it possible to single out Belarus if there are both similar or worse political situations in other EaP states, or there are other states on the EU border that are more corrupt and almost as harsh in their domestic policies? Further, can one effect change through isolation? And will that isolation simply drive Belarus into the arms of Russia? Critics of EU policy have debated these issues at length. Most notable in this regard have been the writings of analysts of the Belarusian Institute of Strategic Studies, Alexei Pikulik and Dzianis Melyantsou. Perusal of one of their contributions (March 2012), written in response to the escalation of the conflict with the departure of the EU ambassadors, is worthwhile as an example of an intelligent and objectively critical approach.

Noting that Minsk may take further steps they note that there are likely to be several consequences of the EU's increased pressure. First, the Belarusian regime is likely to resort to further methods of 'repressive authoritarianism', infringing on political and civil rights, but also signalling the ultimate victory within the state of the security forces over the 'moderate' forces of the political elite. ${ }^{6}$ Further, they

6 The topic is beyond the confines of this paper, but the growing power and dissensions within the security forces have been much discussed. These forces are currently under the control of the president's son Viktar Lukašenka and suspected of involvement in a number of serious incidents during the Lukašenka presidency that have never been fully explained. They include the 1999-2000 disappearances, 'terrorist' attacks in 2006, 2008, and the deadly explosion of 11 April 2011 that killed 12 people and injured hundreds at the Kastričnickaja metro station in central Minsk (two young men from Viciebsk were executed for allegedly detonating the bomb in March 2012), as well as the death of Aleh Biabienin, founder of the Charter'97 web site, on 3 September 2010 (designated a suicide by the inquiry). One author has noted that the security forces have created a 'climate of fear' within Belarusian society (Leshchenko 2008, 1429). 
believe it signals the further de-legalization and dissembling of institutes and structures of independent political and civil society. Third, it will result in the loss of possibilities of institutional and technological modernization of the Belarusian economy through European investment as well as the influence of European values that that process might bring.

Fourth, they fear the 'Cubanization' of the Belarusian opposition, part of which would likely start to operate in exile with concomitant loss of influence over events in Belarus. All these scenarios would strengthen the grip of Russia over Belarus and may lead to the loss of sovereignty and even statehood. The authors proceed to criticise what they perceive as the position of the 'emotional minority' that supports sanctions because of the suffering incurred from the 'repressions of 20102011', which in their view is understandable but misguided because they will not bring about the downfall of the regime (Melyantsou and Pikulik 2012).

In short therefore, they argue, sanctions are counter-productive and dangerous; and they will not benefit the residents of Belarus. That there is some truth in their analysis is evident from the growing population of Belarusian émigrés, particularly in Poland and the Czech Republic. Logically it may be politic for the EU to keep lines of communication open at both higher and lower levels of Belarusian society.

\section{The Russia Option}

Returning to the question posed at the beginning of this paper, whether Belarus will be forced to sell valuable state assets to Russia, recent reports suggest that whereas Russia is likely to put pressure on Belarus, public opinion in the latter country is generally opposed to sale of companies to Russian investors. According to the September 2012 opinion poll of the Independent Institute for Social-Economic and Political Research (IISEPS), only $10 \%$ of those polled regarded the sale of Beltranshaz to Russia's Gazprom as a positive step; $30 \%$ saw it as a negative development but thought that Belarus had little choice; and $43.3 \%$ agreed that it should not have been sold at all. Regarding the potential sale of Belaruskali, only $7.6 \%$ were positive, $17.5 \%$ were negative but thought it acceptable if the price were very high, and $58.7 \%$ were opposed (IISEPS 2012a). Lukašenka also started to express reservations about privatization of state companies, by emphasizing that important factories should be controlled predominantly by the state (Manenok 2012). ${ }^{7}$

Belarus is also heavily reliant on exports for the makeup of its GDP and thus it is illogical from a financial perspective to sell large companies for short-term gains

7 The comment was made with reference to the return to state ownership of confectionary enterprises 'Kamunarka' and 'Spartak'. 
that cannot be repeated. Such situation may explain the president of Belarus' frequent contradictory moves in which he appears to be ready and willing to sell companies to Russia but then either baulks or raises the price beyond levels at which the enterprises are valued.

From the Russian perspective, Belarus does not seem to have many valid options. According to one account, plans to attract foreign investment in 2012 were not even $20 \%$ fulfilled. The IMF mission of late 2012 was not expected to offer any further credits to Minsk. ${ }^{8}$ Former Chair of the National Bank Stanislaŭ Bahdankievič is cited as stating that government plans for an $8.5 \%$ growth in GDP were unrealistic, and the authorities are overspending on law enforcement (\$1.23 billion), with the entire infrastructure of transport, agriculture, forestry, construction, and industry receiving only $\$ 2$ billion, and just $\$ 176$ million on science and research.

Negotiations are under way for the sale of controlling shares in a variety of companies: oil refineries, the cell phone company MTS, the MAZ trucking company, Belaruskali, and Belavia the state airline, though the prospect of the purchase of the Belarusian postal service (Belpošta) by the Russian service had been shelved. In each instance the main stumbling block was over prices, with the Belarusian side maintaining that the Russian offers were too low. The writer believes that Russia holds all the cards in these negotiations, because it can discontinue credits, raise oil and gas prices, and close its prices to a variety of Belarusian exports, such as milk, meat, and textiles. In addition, Russia can increase gas prices as Belarus in 2012 was paying only $\$ 160$ per thousand cubic meters compared to over $\$ 460$ for Ukraine. Lukašenka's riposte on oil refineries was that if sold to Russia, then Belarus should be allowed to take part in extracting 10 million tons of oil and 10 billion cubic meters of gas annually from Russia (Shveits 2012).

All the above comments presuppose that Russia wishes to make life difficult for the Belarusian government. A Western analyst also has noted that Belarus' trade deficit to Russia rose from \$8 billion in 2010 to \$11 billion in 2011 despites its membership in the Customs Union with Russia and Kazakhstan (Ioffe 2012). Logic suggests, however, that a weak regime in Minsk that is reliant on Russian loans is preferable to the collapse of the Lukašenka administration, whatever the frustration of dealing with it. The most critical feature of Belarus from

8 The IMF mission under David Hofman visited Minsk on 19-29 October 2012. Initial reports suggest that the agency gave a strong warning to Belarus that although a more rigorous economic policy in 2011 had reduced inflation and enabled a more stable currency, urgent measures were required: 'Nevertheless, the initial success was followed by the fast reduction of the refinancing rate and rapidly rising salaries in real terms. Once again the factors now lead to the emergence of pressure on prices and the exchange rate. Due to the pressure it is necessary to take decisive and consistent reactive economic policy measures to keep the economy stable', remarked David Hofman. 
Moscow's perspective is its geostrategic location and as an alliance partner. That is perhaps why Russia refused to back any of the political alternatives to Lukašenka during the 2010 presidential elections in Belarus, despite intensive discussions of several candidates in Moscow, as well as deteriorating relations between the respective leaders at that time.

Paradoxically therefore even though Belarus' dependence on Russia has increased over the years of Lukašenka's presidency, Moscow cannot dictate policy to Minsk. Nor has it tried to do so other than on specific issues such as prices for gas and oil, or payment of outstanding debts. In other words, Russia has to date never fully used its economic advantages to try to remove Lukašenka. Without Russian loans, or loans from Russian-led entities like the Eurasian Economic Community, Belarus would be in serious difficulties. Further, now that Belarus has joined the Customs Union with Russia and Kazakhstan, it has entered into a partnership that fosters closer economic integration, especially by reducing nontariff barriers and ultimately one assumes by the creation of supranational structures for further cooperation (Pyrkalo 2012).

In some respects, both leaderships - specifically the presidency of Vladimir Putin rather than that of Dmitry Medvedev - have much in common. Both are authoritarian, provide a strong role for security forces, fear the potential power of NATO, and have a common and favourable view of the Soviet past, and the fraternal relationship within it of Russia and Belarus, particularly during times of crisis such as the 'Great Patriotic War' (Manaev, Manayeva and Juran 2011, 9495). ${ }^{9}$ Both continue to mark Soviet anniversaries and to some extent revere the former Soviet leaders (Russia Today 2012, Dyńko 2010). ${ }^{10}$

Such outlooks belie the difference modes of economic development and the petty squabbles that permeated the relationship in the first decade of the $21^{\text {st }}$ century. Lastly, the two leaders are of one mind in opposing Western 'interference' on issues such as democratic behaviour, human rights, and political prisoners. It at least provides a framework, along with the more obvious ties as Slavic neighbours who for the most part speak a common language. This sort of rationalising is perhaps another reason why Russia has rarely given ultimatums to Belarus. The other is that Belarus always had some options, however difficult they may be to access -

9 But there are limitations to the analogy with the USSR. Oleg Manaev, Natalie Manayeva, and Dzmitry Juran have noted Belarus' gradual departure from the Soviet heritage and the fact that, in contrast to Soviet times, there are numerous political parties in Belarus, as well as some NGOs, an independent media exists under pressure, and private companies compose between 25-30\% of GDP.

${ }^{10}$ During an October 2012 interview with the RT network, Lukašenka insisted that Lenin and Stalin should not be demonized: 'I'm far from a Stalin - Lukashenka' (Russia Today 2012) By contrast Prime Minister Medvedev was stating that the Stalin regime deserved to be treated harshly for declaring war on its own people. 
loans from China or further loans from the IMF, which would come with various conditions attached, being two examples.

\section{Conclusion}

In the short term at least, the Lukašenka regime will survive in some form, as long as it can secure more short-term loans, control inflation, and build up foreign currency reserves to reasonable levels. Prognoses about its economic collapse do not seem to be borne out by the current situation, difficult though it may be. In the political arena, though the president's popularity has fallen somewhat, ${ }^{11}$ there is no logical replacement in the wings.

The opposition has been hit hard by the repressions, and within the government, there is no overt dissension, even though there are differences about the country's future direction. Rather the regime has adopted a siege mentality - the president has advocated the creation of territorial armies under oblast governors (BelTA, 2011) - this follows earlier rhetoric about the authority of the CSTO to intervene in domestic crises of its member states and the draft laws that would empower the KGB as a 'state within a state'. Lukašenka has made public references describing his abhorrence for NATO's treatment of former Libyan leader Muammar Gaddafi, which he described as worse than that administered by Nazis (ITAR-TASS 2011). The analogy between Libya and Belarus is no doubt far-fetched, but in the minds of authoritarian leaders and dictators, such fears are rarely far from the surface.

The EU - Belarus relationship is thus at an impasse, but while it is hardly incumbent on Brussels to reignite engagement with Minsk under any circumstances, it can still ponder the various alternatives. On the other hand, the EU could follow the course suggested by David Kramer of Freedom House, i.e. the complete isolation and non-engagement with the Belarusian regime without concern about pushing Belarus into Russian hands (Charter'97 2011).

Admittedly, if the EU responds to Lukašenka's overtures, then it may have to compromise on various questions, including those of civil rights and free elections it already conceded implicitly in its September 2011 statement that the president would likely remain in office. It is not an easy choice and it is made even harder by the EU's preoccupation with the financial plight of members like Greece and Italy.

Sanctions sometimes bring results, but more often they are symbolic reprisals that may denote a justifiable concern for political prisoners rather than a means to

\footnotetext{
${ }^{11}$ The March 2012 poll by the Independent Institute for Socio-Economic and Political Research indicated that the president's standing is around 34.5\%, up from 20.5\% in September 2011. But none of the opposition candidates could muster double figures, perhaps because they have been incarcerated, placed under house arrest, or moved abroad since the 2010 elections.
} 
effect regime change or promote democracy. The latter are not at present options for the EU. Instead it can engage modestly with Belarusians at a number of levels - educational exchanges, border security, trade, technology, and enhanced investment where it can compete with Russian capital when Belarus privatizes major companies. In this way, the EU can keep open a number of options while taking into account that several of its members border on Belarus and have an interest in maintaining some engagement at various levels.

Similarly within the Eastern Partnership, there is no logic to singling out Belarus unless it is assumed that a small post-Soviet state lacking natural resources can be expected to move smoothly toward a democratic transition without problems. Rather than commit its future either to partnership with Russia or the EU, the Belarusian leadership has fostered a form of civic nationalism based on an independent state, while the regime has ensured its residents are provided with the basic means of existence in a paternalistic society under a president referred to as 'Baćka' (father) (Leshchenko 2008).

In general, the Belarusian electorate appears to be passively satisfied with the status quo and wary of the sort of reforms introduced through shock therapy in Russia. The president frequently refers to period 1991 to the start of 1994 in Belarus as one of great deprivation and growing poverty, relieved only when he took over as president. In the same way he has fostered an image of a state surrounded by enemies, among which most often cited have been NATO and the United States, but more recently, the target has been the European Union seeking to push its own principles on a foreign and sovereign country.

But does the EU represent something desirable to the people of Belarus or do they prefer development without firm commitment to international unions of the east or west? It is well established that the public respond to certain criteria during election campaigns, foremost of which are sustainable living standards, security, and avoidance of conflicts.

To date, the Lukašenka presidency has managed to provide most of these, albeit through somewhat unusual means, such as the resale of subsidised Russian imports, and despite the economic issues of 2009-11, including rampant inflation. Perhaps democracy, freedom of expression, and a free media are not key priorities among the population, though that is not to say that there is much support for the values of the former Soviet Union, the official state media, or deeper integration with Russia.

Some younger Belarusians do look toward Europe, but remain frustrated with Schengen visa fees of 60 Euros to cross the border into the EU, a longstanding problem that could be resolved more simply than many other issues. In the 
meantime, the current imbroglio does little to enhance the stature of either side, but nor does it change much. Trade between the EU and Belarus continues today at a high level, as does engagement on a number of levels and it is logical that they should continue.

The depiction of a small republic of 9.4 million caught between two alternatives is perhaps a simplistic portrayal. It is not a direct choice between Brussels and Moscow. The relationship between the EU and Russia is increasingly intertwined. Individual EU countries have placed priority on firm economic and political links with Russia. Belarus also has other alternatives, as its negotiations and trade with China illustrate (Charter'97 2012a). ${ }^{12}$ But the EU and Russia are its immediate neighbours: one a powerful economic bloc, the other a military and political power in the region. For many years, the Belarusian president has survived in part by operating in a space created between them.

In other words, whether or not the EU and Russia have conflicting interests, Belarus portrays them as two separate and antithetical power blocs that are competing for the allegiance of Belarus. And to some extent the two neighbours reciprocate this perception: the EU imposes sanctions after Belarusian elections; Russia recognizes these elections as free and fair. And if Russia imposes too much pressure, the Belarusian authorities can always release high-level political prisoners to gain leverage with the Europeans. Essentially this is a political card game, but the rules have been established less in Brussels and (to a lesser extent) Moscow than in Minsk. In this way, the dealer may have the weakest hand, but he is nonetheless still largely in control of the game as long as the other players remain at the table.

It is also possible that critiques of EU policy are overblown. Despite the difficulties of coming up with consensus among its members, as well as the partial effectiveness of sanctions applied to individuals, there is some evidence that many Belarusians are interested in the EU and support closer relations with it. The December 2012 issue of the IISEPS News, which carries out quarterly polls in Belarus on attitudes toward Russia and the EU noted the following: if given a choice between integration with Russia and joining the EU, $43.4 \%$ of respondents would opt for the former, and $37.7 \%$ the latter (IISEPS 2012b).

On the other hand it commented that at a deeper level, the gradual swing from Russia to the EU was ever more apparent, especially on the level of sharing technology and providing credit - it was less evident in the area of implementing reforms. In other words, the European option is at least competitive, but perhaps official propaganda about the iniquities of outside powers demanding reforms and changes has had some impact.

${ }^{12}$ I have been unable to corroborate this report or compare it with other sources. 
The poll does imply that the 2007 analysis of Jarabik and Rabagliati was somewhat pessimistic and that there is greater awareness of the EU and its institutions in Belarus today than there was five years ago. In this respect it may not be necessary for a complete rethinking of EU policy. Perhaps it has been a victim of the clever strategic moves of a wily leader, but there is evidence that its moderate policies have had a gradualist effect, as has the decision to apply milder sanctions, rather than those that would seek to have a serious economic impact.

Can Belarus continue its policies of manipulation and controlling the political card game? Perhaps, but it may require the entry into the game of additional partners, such as China, with which has already started a significant economic partnership, and in the shorter term, allied states like Venezuela (assuming Belarus can resume the sort of relationship it had with the late president Hugo Chavez), which can reduce its dependence on Russian oil. On the other hand, its main partners will continue to be Russia and the EU, and in both these areas, its options are increasingly limited. Russia's attitude is now sterner, with little compulsion to return to the era of subsidised energy resources for its partners. Though integration efforts have been slow, the founding of the Customs Union, and Belarus' increasing need for further loans and credits make Russia's position vis-à-vis Minsk stronger. Russia's position is further strengthened by the coolness of the Minsk-Brussels relationship and the EU's growing awareness of the futility of playing by Lukašenka's rules. What the EU still needs to do - and here Jarabik and Rabagliati's conclusions retain their relevance - is raise public awareness of why democratic reforms are beneficial, which it can only do by increasing its penetration of grassroots society. The IISEPS poll suggests that thus far, it has failed in this particular quest, but that is not to say that no progress has been made.

\section{References}

Agence France Presse, 2011. 'Lukashenko Says West “Strangling” Crisis-Hit Belarus', 9 September, cited in <http://www.ipotnews.com/index.php?jdl=Lukashenko_says_West_strangling_crisis_hit_Bela rus\&level2=newsandopinion\&level3=\&level4=BANKING\&id=623684\&popular=>. [accessed 16 March 2013].

Belsat, 2012. 'Lithuanian Minister against Sanctions on Belarus', 13 April http://belsat.eu/en/wiadomosci/a,7910, lithianian-minister-against-sanctions-on-belarus.html>. [accessed 16 March 2013].

BelTA, 2011. 'Belarus Getting New Army', 4 November

$<$ http://news.belta.by/en/main_news?id=666220>. [accessed 16 March 2013].

- - - 2012a. 'Banning EU Entry to Judges Contradicts Constitutions of EU States', 20 April $<$ http://news.belta.by/en/news/politics?id=679998>. [accessed 16 March 2013]. 
- - - 2012b. 'IMF Tells Belarus to Keep Down Government Program Lending', 29 October $<$ http://news.belta.by/en/news/econom?id=697366>. [accessed 1 November 2012].

Bildt, Carl, Karel Schwarzenberg, Radek Sikorski and Guido Westerwelle, 2010. 'Lukashenko the Loser', The International Herald Tribune, 23 December.

Bosse, Giselle, 2009. 'Challenges for EU Governance through Neighbourhood Policy and Eastern Partnership: the Values/Security Nexus in EU-Belarus Relations', Contemporary Politics, 15, 2 (June), pp. 215-24.

Buhaj, Mikola, 2010. 'Lukašenka kapituliavaŭ i daje harantyju, što u Rasii taho nie viedajuć', Naša Niva, 3 July <http://nn.by/?c=ar\&i=40579>. [accessed 16 March 2013].

Cassatas, Peter, 2008. 'EU Lifts Travel Ban on Belarusian Leaders', Atlantic Update, 14 October $<$ http://www.acus.org/atlantic_update/eu-lifts-travel-ban-belarusian-leaders>. [accessed 13 March 2013].

Center for European Policy Analysis and Freedom House, 2011. 'Democratic Change in Belarus: A Framework for Action', September, Washington DC.

Česká Pozice, 2011. 'Mikhalevich Applies for Czech Asylum', 18 March $<$ http://m.ceskapozice.cz/en/news/politics-policy/belarus-presidential-candidate-applies-czechasylum $>$. [accessed 11 November 2011].

Charles, Mathew, 2011. 'Belarus “Tortured Protesters in Jail”, BBC News Europe, 1 March $<$ http://www.bbc.co.uk/news/world-europe-12606265>. [accessed 16 March 2013].

Charter'97, 2010. 'Dalia Gribauskaite: Garant stabil'nosti Belarusi - eto eio liudi', 22 November 2010

<http://charter97.org/ru/news/2010/11/22/34003/>. [accessed 8 December 2010].

- - - 2011. 'David Kramer: We Should Tighten Noose around Lukashenka', 1 June <http://charter97.org/en/news/2011/6/1/39186. [accessed 16 March 2013].

- - 2012a. 'Belarus prymie 650 tysiač kitajcaŭ', 13 December <http://charter97.org/be/news/2012/12/13/62741/>. [accessed 16 March 2013].

- - - 2012b. 'Dzmitry Bandarenka: Lukashenka Knew the Entire Belarus Would Rise on 20 December', 20 December <http://charter97.org/en/news/2012/12/20/630>. [accessed 16 March 2013].

CIWR, 2011. 'Twelve Years without Viktor Gonchar and Anatoly Krasovsky', 16 September $<$ http://udf.by/english/main-story/47218-12-years-without-viktor-gonchar-and-anatolykrasovsky.html>. [accessed 12 November, 2011].

Council of the European Union, Press release, 30 September 2011.

Coyle, James J., 2011. 'Russia Buying Belarus', Eurasian Energy Analysis, 24 June <http://eurasianenergyanalysis.blogspot.ca/2011/06/russia-buying-belarus.html>. [accessed 10 April 2012].

Dyńko, Andrej, 2010. 'Čym byla dlia Bielarusi taja pieramoha?', Naša Niva, 9 May $<$ http://nn.by/?c=ar\&i=38284>. [accessed 16 March 2013].

European Commission, 2006. 'EU-Belarus: New Message to the People of Belarus', Press releases RAPID, 21 November

$<$ http://europa.eu/rapid/pressReleasesAction.do?reference=IP/06/1593\&format=HTML\&aged=0 \&language $=\mathrm{EN}>$. [accessed 14 April 2012]. 
- - , 2011a. 'First EU-Belarus Dialogue on Economic and Financial Issues', 12 October $<$ http://ec.europa.eu/economy_finance/articles/international/2011-10-06-first-eu-belarusdialogue_en.htm>. [accessed 13 November 2011].

- - - 2011b. 'The Policy: What is the European Neighbourhood Policy?', European Neighbourhood Policy <http://ec.europa.eu/world/enp/policy_en.htm>. [accessed 7 November 2011].

EPP Group in the European Parliament, 2010. 'Sakharov Prize - Milinkevich, EPP-ED Candidate, Wins the 2006 Award', 26 October <http://www.eppgroup.eu/press/showpr.asp?PRControlDocTypeID=1\&PRControlID=5405\&PR ContentID=9629\&PRContentLG=en>. [accessed 12 November 2011].

European Union External Action, 2006. 'What the European Union Could Bring to Belarus', November <http://eeas.europa.eu/delegations/belarus/documents/eu_belarus/non_paper_1106.pd>. [accessed 12 April 2012].

EU Business, 2011. 'EU Must Be Firm on Belarus Political Prisoners: Ministers', 3 September $<$ http://www.eubusiness.com/news-eu/belarus-diplomacy.bzr>. [accessed 16 March 2013].

- - , 2012. 'EU Sanctions “Repressive” Belarus', 23 March http://www.eubusiness.com/newseu/belarus-politics.ft1>. [accessed 14 April 2012].

EU Council Secretariat, 2011. 'The EU's Eastern Partnership, European Union Fact Sheet', 29/30 September.

International Monetary Fund, 2011a. 'Statement by the IMF Mission to the Republic of Belarus', Press Release No. 11/229, 13 June <http://www.imf.org/external/np/sec/pr/2011/pr11229.htm>. [accessed 14 April 2012].

- - , 2011b. 'Statement by the IMF Mission to the Republic of Belarus', Press Release No. 11/368, 17 October <http://www.imf.org/external/np/sec/pr/2011/pr11368.htm>. [accessed 16 March 2013].

Ioffe, Grigory, 2012. 'Belarus and Russia: Affinity and Dependency', Eurasian Daily Monitor, 9, 198, 30 October

$<\mathrm{http} / / /$ www.jamestown.org/programs/edm/single/?tx_ttnews[tt_news]=40035\&tx_ttnews[backP id] $=27 \& \mathrm{cHash}=31 \mathrm{a} 2 \mathrm{dec} 6 \mathrm{c} 749 \mathrm{e} 3392666345 \mathrm{~b} 562 \mathrm{ae} 2 \mathrm{db}>$. [accessed 1 November 2012].

- - , 2012. 'Economic Normalization and European Sanctions', Eurasian Daily Monitor, 5 April, 9, 68 <http://www.jamestown.org/single/?no_cache=1\&tx_ttnews[tt_news]=39231priority $>$. [accessed 14 April 2012].

IISEPS (Independent Institute for Social-Economic and Political Research), 2012a. 'Natsional'nyi Opros 24 Sentiabr' - 3 Oktiabr' 2012 g.' <http://www.iiseps.org/data12-391.html>. [accessed 16 March 2013].

- - , 2012b. Monitoring of Public Opinion in Belarus' <http://www.iiseps.org/ebullet124.html>. [accessed 16 March 2013].

Interfaks-Zapad, 2011. 'Lukashenka: v Belarusi sozdaetsta fakticheski novaia armiia' , 4 November $<$ http://www.interfax.by/news/belarus/101468>. [accessed 5 November 2011].

ITAR-TASS, 2011. 'NATO Worse than Nazi [sic!] in Treating Gaddafi - Lukashenko', 4 November $<$ http://www.itar-tass.com/en/c32/264409.html >. [accessed 16 March 2013].

Jarabik, Balazs and Alastair Rabagliati, 2007. 'Buffer Rus: New Challenges for EU Policy towards Belarus', FRIDE, Working Paper 34, March 2007. 
Jozwiak, Rikard and Richard Solash, 2012.'Why did Slovenia Spare Belarusian Mogul from EU Sanctions?', RFE/RL, 28 February

$<$ http://www.rferl.org/content/whats_behind_slovenia_efforts_to_spare_belarus_chizh_eu_sancti ons_minsk_lukashenko/24498166.html . [accessed 2 February 2013).

Korostoleva, Elena, 2009. 'The Limits of EU Governance: Belarus's Response to the European Neighbourhood Policy', Contemporary Politics, 15, 2 (June), pp. 229-45.

Korovenkova, Tat'iana, 2010. 'EU Ambassadors Leaving Belarus', Naviny.by, 1 March <http://naviny.by/rubrics/english/2012/03/01/ic_articles_259_177034/>. [accessed 14 April 2012].

_- - , 2013. 'Lukashenko i Makei obsudili puti dal'neishei aktivizatsii raboty s Zapadom', Tut.by, 29 January <http://news.tut.by/politics/332453.html>. [accessed 2 February 2013].

Kudrytski, Aliaksandr, 2011. 'Lukashenko Slams Government Plan to Stabilize Economy', Bloomberg, 10 November <http://www.bloomberg.com/news/2011-11-10/lukashenko-slamsgovernment-plan-to-stabilize-belarus-s-economy.html>. [accessed 13 November 2011].

- - - 2012. 'Belarus Trade Deficit Narrowed 43\% in 2011 as EU Exports Surged', Bloomberg, 16 February <http://www.bloomberg.com/news/2012-02-16/belarus-trade-deficit-narrowed-43-in2011-as-eu-exports-surged.html>. [accessed 3 March 2013].

Kryat, Dmitrii, 2012. 'Vsio o privatizatsii', Belarus' Segodnia, 31 March http://www.sb.by/post/128793/. [acessed 16 March 2013].

Leshchenko, Natalia, 2008. 'The National Ideology and the Basis of the Lukashenka Regime in Belarus', Europe-Asia Studies, 60, 8, pp. 1419-33.

Lisichonak, Siarhej, 2012. 'Why the Eastern Partnership Fails to Reach Belarus', Belarus Digest, 29 March <http://belarusdigest.com/print/8609>. [accessed 13 April 2012].

Manaev, Oleg, Natalie Manayeva and Juran, Dzmitry, 2011. 'More State than Nation: Lukashenko's Belarus', Journal of International Affairs, 65, 1 (Fall/Winter).

Manenok, Tat'iana, 2012. 'Mobilizatsiia natsionalizatsii', Belarusy i Rynok, 40 (1024) 22-28 October. <http://belmarket.by/ru/196/60/15440>. [accessed 1 November 2012].

Marples, David and Uladzimir Padhol 2010. 'Belarus: a Most Peculiar Election. Part 2', Open Democracy Russia, 14 December <http://www.opendemocracy.net/od-russia/david-marplesuladzimir-padhol/belarus-most-peculiar-election>. [accessed 3 March 2013].

Marples, David, 2011. 'Conflicting Reports on the Sale of Belarus Potash Company', Eurasian Daily Monitor, 8, 118, 20 June

$<\mathrm{http}: / /$ www.jamestown.org/single/?no_cache=1\&tx_ttnews[tt_news] $=38074>$. [accessed 3

March 2013].

- - , 2011a. 'Lukashenka's Friends', Eurasian Daily Monitor, 8, 161, 19 August $<\mathrm{http}: / / \mathrm{www} . j a m e s t o w n . o r g /$ single/?no_cache $=1 \&$ tx_ttnews[tt_news] $=38350>$. [accessed 14 April 2012].

Melyantsou, Dzianis and Pikulik, Alexei, 2012. 'Konflikt s ES: v poiskakh zdravogo smysla', Belarusian Institute for Strategic Studies, 10 April <http://ru.democraticbelarus.eu/news/konflikts-es-v-poiskakh-zdravogo-smysla>. [accessed 14 April 2012].

_- -, (2012)a. 'Posledstviia konflikta s ES: chto budet s rodinoi i s nami?', Naviny.by, 16 March <http://naviny.by/rubrics/opinion/2012/03/16/ic_articles_410_177195/>. [accessed 14 April 2012].

Milinkievič Aliaksandr website, <http://by.milinkevich.org>. [accessed 25 September 2010]. 
Ministry of Finance of the Russian Federation, 2011. 'Belarus Loan to be Granted on Condition of 3-year Privatization Program Approval - Kudrin', 20 May

<http://www.minfin.ru/en/pressoffice/quotes/printable.php?id4=12754>. [accessed 2 February 2013].

Naša Niva, 2012. 'Miadźviedzieŭ: Stalin vajaval z ŭlasnym narodam, a heta najciažejšaje zlačyństva', 30 October <http://nn.by/?c=ar\&i=82777> [accessed 31 October 2012].

National Legal Internet Portal of the Republic of Belarus, 2012. 'Belarus Ready to Sell Belaruskali for \$30bn’, 30 March <http://law.by/main.aspx?guid=80633>. [accessed 15 April 2012].

Naviny.by, 2011. 'Belarus Allowed to Pay Lower Price for Russian Natural Gas in Latter Half of 2011', 29 November

<http://naviny.by/rubrics/english/2011/11/29/ic_news_259_381624/>. [accessed 30 November 2011].

Organisation of Security and Co-operation in Europe Office in Minsk <http://www.osce.org/minsk> . [accessed 2 February 2013].

Preiherman, Yauheni, 2011. 'Belarus at the EaP Summit in Warsaw: the Meaningless Scandal', Belarus Digest, 3 October <http://belarusdigest.com/print/5983>. [accessed 14 April 2012].

Pulsha, Sergei, 2010. 'Boycott in Favor of Lukashenko', Tretii Put', 15 December $<$ http://3dway.org/en/boycott-favor-lukashenko>. [accessed 16 March 2012].

Pyrkalo, Svitlana, 2012. 'Customs Union of Russia, Kazakhstan and Belarus is First Success in CIS Integration, says EBRD', 7 November

$<$ http://www.ebrd.com/pages/news/press/2012/121107a.shtml>. [accessed 3 February 2013].

Radio Liberty, 2011. 'Mladenov about Lukashenko: the President Seemed Sincere', 19 September, cited in <http://udf.by/english/main-story/47299-mladenov-about-lukashenko-president-seemedsincere.html>. [accessed 16 March 2013].

Rettman, Andrew, 2011a. 'Belarus Resigned to EU Sanctions after Ashton Meeting', EU Observer, 12 January <http://euobserver.com/foreign/31631>. [accessed 16 March 2012].

- - - 2011b. 'EU Imposes Visa Ban on Belarus, Threatens Economic Measures', EU Observer, 31 January <http://euobserver.com/24/31727>. [accessed 14 April 2012].

- - - 2011a. 'EU Offers to Buy Belarus for \$9 Billion', EU Observer, 30 September $<$ http://euobserver.com/enlargement/113794>. [accessed 3 March 2013].

RFE/RL, 2011. 'Belarus Frees Key Opposition Figure', 2 October $<\mathrm{http}: / /$ www.rferl.org/content/belarus_frees_key_opposition_figure/24346193.html $>$. [accessed 14 April 2012].

RIA Novosti, 2011. 'Lukashenko Regime Has no Political Legitimacy', 12 January <http://en.rian.ru/world/20110112/162115504.html>. [accessed 16 March 2013].

$R T$, 2012. 'I'm Far from a Stalin - Lukashenka', 16 October <http://rt.com/politics/lukashenkoconference-belarus-media-542/>. [accessed 1 November 2012].

Shumchenko, Anatolii, 2010. 'Lukashenko pozhinaet to, chto poseial', Belorusskii Partizan, 22 October <http://www.belaruspartisan.org/politic/168186>. [accessed 16 March 2013].

Shveits, Maksim, 2012. 'Belorusskaia zasada', Kommersant Den'gi, No 42, (899), 22 October $<$ http://www.kommersant.ru/doc/2040906?isSearch=True>. [accessed 27 October 2012].

Schwirtz, Michael, 2011. 'Belarus Accuses Poland, Germany, of Takeover Plot', The New York 
Times, 14 January http://www.nytimes.com/2011/01/15/world/europe/15belarus.html?_r=0>. [accessed 3 March 2013].

Silitski,Vitali, 2009. 'The Milk Split by the Milk War', European Voice, 24 June <http://www.europeanvoice.com/article/2009/06/the-milk-split-by-the-milk-war/65274.aspx>. [accessed 14 April 2012].

Telegraf.by, 2011. 'Ashton Sets Ultimatum to Martynov', 12

<http://telegraf.by/2011/01/ashton_sets_ultimatum_to_martynov>. [accessed 20 January 2011].

-----, 2011. 'IMF: Belarus Should Tighten Economic Policies', 17 October $<$ http://telegraf.by/en/2011/10/mvf-belarusi-nujno-ujestochit-ekonomicheskuyu-politikuobnovlyaetsya>. [accessed 13 November 2011].

_- -, 2012a. 'Ministry of Transport of Lithuania: EU Policy towards Belarus Should not Harm Lithuania', 13 April <http://telegraf.by/en/2012/04/mintrans-litvi-politika-es-v-otnoshenii-belarusine-doljna-vredit-litve>. [accessed 14 April 2012].

---, 2012b. “"Economic Well-Being” of Belarusians Getting Stabilized', 29 March $<$ http://telegraf.by/en/2012/03/nisepi-ekonomicheskoe-samochuvstvie-belorusov-stabiliziruetsya> . [accessed 11 April 2012].

United Civil Party, <http://www.ucpb.org/component/content/article/62522>. [accessed 30 December 2010].

Vashkevich, Andrei, 2010. 'Ploshchad' - 2010', Narodnaja Volia, 20 December <http://www.nvonline.info/by/136/news/25153/>. [accessed 16 March 2013].

Volianiuk, Vitalii, 2010a. 'Pozhivem - uvidim', Belarus' Segodnia, 6 July $<$ http://www.sb.by/post/102280/>. [accessed 16 March 2013].

- - -, 2010b. 'V polnyi kolos', Belarus' Segodnia, 17 July <http://www.sb.by/post/102807/>. [accessed 16 March 2013]. 